\title{
Discussion on Improving Quality of Metal Structure Graduation Design
}

\author{
Yang Mingliang \\ Taiyuan University of Science and Technology \\ Shanxi, China \\ yangmingliang1997@163.com
}

\author{
Chang Zhengyan \\ Taiyuan University of Science and Technology \\ Shanxi, China \\ carpenter20081@163.com
}

\author{
Cheng Luyang \\ Beijing Materials Handling Research Institute \\ Beijing, China \\ ly-926@163.com
}

\begin{abstract}
The graduation design is to cultivate students' comprehensive use of the knowledge and skills, to analyze and solve the technical problem of the general engineering professional range, training students to establish the correct design ideas, grasp the general procedure, standard and method of Engineering design. However, the graduation design is a comprehensive use of students only learn the knowledge and skills to solve practical problems, from unfamiliar to familiar with, the need for a process, in this process in order to improve the quality, the key is to strengthen the guidance. In the design process, the professional class teacher has accumulated some very good practice. To improve the quality of graduation design, the study analyzes the current problems, the purpose and function of metal structure in the graduation design. The countermeasures of improving the quality of design are put forward from the screening of graduate design topics, giving full play to regulate the guidance of teachers, and other aspects.
\end{abstract}

Keywords-Graduation design; Teaching practice; Skill training

\section{INTRODUCTION}

The graduation design is the engineering college students during the last comprehensive summary of the teaching practice. Students finish all the provisions of a comprehensive training course after this stage, combining theory and practice most closely, grasp this part of the training of basic skills can make the students' ability is greatly improved. The author is to guide the practice of graduation design, shallow talk about how to improve the quality of graduation design[1].

\section{EXISTING PROBLEMS}

\section{A. Old design topics}

The metal structure design obsolete, analog "fake" title, the same year, the reference map and the accumulation of information is complete, students can copy, it is convenient and labor-saving, no active work, lack of independent thinking ability to solve problems, students gain experience and is not, is not conducive to the cultivation of the ability.

\section{B. Engineering practicecombination ignored}

The combination of graduation design and engineering practice, the design conditions and the actual conditions of the project is far from, and the actual project is out of touch, ignoring the students' innovative consciousness and practical ability training.

The design of the lack of innovation, and some do not even science, or repeat the old subject, either in a link mechanical duplication, lack of training for students, enthusiasm and hurt the students, innovative lost students; on the graduation design guidance is not effective, or the lack of guidance, or let things drift; what frame too dead, leave no room, students can only follow the prescribed order, lack of innovation, practical ability is not exercise.

\section{Without scientific evaluation method}

The evaluation of graduation design performance is lack of scientific nature, and there is no uniform evaluation standard. Teachers often only have their own subjective impression of a given result.

\section{Full Understanding of Purpose of GRAduAtion DESIGN IN TEACHING}

\section{A. Purpose of graduation design}

The graduation design is to cultivate students' comprehensive use of the knowledge and skills, to analyze and solve the technical problem of the general engineering professional range, training students to establish the correct design ideas, grasp the general procedure, standard and method of Engineering design. Through the graduation design, to further consolidate and expand and deepen the knowledge, improve the design, calculation, drawing, preparation of 
technical documents and the correct use of technical information to develop the ability to work independently, rigorous and pragmatic work style, strict in demands, so as to realize students' transition to engineering and technical personnel.

\section{B. Effect of graduation design}

Graduation design is a very important practice process for both students and teachers. It is mainly reflected in the following 4 aspects:

It can improve students' ability in many aspects. Including the comprehensive application of knowledge ability, the ability to discover and solve problems, data query ability, computer application ability, writing ability, oral expression ability, coordination and cooperation ability, etc. It emphasizes the training and training of the ability of the comprehensive application of knowledge, which is an important aspect of the graduation design, which is different from other practical aspects such as curriculum design. A good graduation design topic, usually involves the application of multi professional, professional basic course of knowledge, sometimes involves knowledge of related disciplines.

It can shorten the students in the future work of the adaptation period, so that they enter the "role" as soon as possible, to play a role.

It can strengthen the communication between teachers and students, found that the lack of teaching, as far as possible to narrow the differences between teaching and learning.

We can explore the excellent talents in the students and find some valuable research results.

\section{Premise of Improving Quality of Graduation Design Beingto Design Graduation Project Seriously}

The topic selection is a prerequisite to improve the quality of graduation, should meet the requirements stipulated in the specific teaching, summed up in twenty words: the width of the right, appropriate depth, avoiding the trivial, consider employment, combined with scientific research.

\section{A. Right width}

The graduation design is just more than ten weeks, the topic is too wide, the students will be in a short time to finish the graduation design task, and no practical topic is too narrow, the equivalent of curriculum design, the workload is obviously insufficient, is not conducive to the students to give full play to the knowledge base, so it should be considered in specialty and students' interest in hobbies on the choice of their professional strengths, interests and larger width of the right questions.

\section{DePTH Suitable}

A selection of topic content is the key to enable students to make full use of the basic theory, learned the basic knowledge and basic skills to independently solve practical problems, appropriate depth is conducive to students' comprehensive ability, the theory of data analysis ability, plan ability, design ability, drawing ability and organizational planning ability etc. culture is too deep or too shallow, often half of the past times, is not conducive to learning knowledge, comprehensive training and cultivation of the ability of organic. 3 to avoid deficiency on the real.

\section{A. Avoid deficiency on the real}

The ultimate goal of the graduation project is to train the students to solve the practical engineering problems, and to realize the transformation of the students to the engineering and technical personnel. So the design should be real, the main choice of the current industry issues of concern or need to solve practical problems in production, as far as possible to practice, design will be a student in an engineering and technical personnel to the position requirements: to solve the problems in the design process, the way to solve this problem, can use the data are used to solve practical problems as a starting point, drawing and painting strictly according to the requirements of industrial production, not only to draw the part's shape and size, but also correctly marked roughness, shape and position tolerance and the necessary technical requirements, according to the drawings can reach into finished product level. In recent years, the graduation project has been using real issues, received a good effect, the use of the unit evaluation is very high.

\section{B. Consider employment}

Most of the students before the graduation, has implemented the work unit, so you can consider nature and professional needs for future work to set up a problem, improve the enthusiasm of the students, on the other hand, for future work to lay a solid foundation.

\section{Combined with scientific research}

Combining with scientific research teachers' scientific research topics, will be divided into several sub topics teacher assigned to students, let students "the real thing" to do the engineering practice so that students in the. Teachers and students are to find information, analysis, selection, process calculation, to solve the practical problems of production. In this way, we can cultivate students' scientific research awareness and strict scientific style, grasp the working procedures of scientific research, and provide basic training for students to go to work to carry out research work.

\section{Give Full Play to Role of Teachers Being Key to IMPROVE QUALITY OF GRADUATION}

The graduation design is a comprehensive use of students only learn the knowledge and skills to solve practical problems, from unfamiliar to familiar with, the need for a process, in this process in order to improve the quality, the key is to strengthen the guidance. In the design process, the professional class teacher has accumulated some very good practice:

\section{A. Reasonable arrangement design progress}

Graduation design is actually a scientific research process; the process should be divided into four stages. 
The first stage is from the design task, make students familiar with the subject matter, guide them to review or selfpreliminaries about, go to the library and read the relevant technical materials, develop their ability to use data and independent experiments, seize the key to solve the problem, finally write the design of graduation. In the design of the program, teachers can give students to guide, take the value of the way, guide the students to use the knowledge they have learned, for the problem to be solved to explore their own, to teach them to practice. A comprehensive, thorough and rigorous consideration, repeated comparisons, to plan in accordance with the argument, not only advanced technology and the economic and reasonable principle to find out the optimal plan. These stage teachers can't do.

The second stage is to let the students according to the requirements of the design program to carry out the comprehensive graduation design work, guidance teachers should guide students to carry out strict thinking, reasonable design and calculation. In assembling and debugging, the problems of book knowledge is inconsistent with the actual situation, teachers should inspire and guide the students to think, analysis, comparison, let them find the problem, find a solution to the problem, so that students have the ability to exercise in debugging and improving.

The third stage is to complete the graduation thesis. Guide teachers should teach students how to design according to their own graduation, to write a qualified graduation thesis.

The fourth stage of the organization of the respondent, assessment results.

In the design of the primary stage, should be based on the workload of each component, the degree of difficulty to divide the total time, the appropriate arrangements for each stage of the time required, the design can be completed on schedule.

\section{B. Strengthen usual counseling work}

Methods based on the inspiration and guidance, the students' enthusiasm and creativity should be combined together to grasp the main aspects of the major contradictions and conflicts.

\section{Strengthen application of CAD/CAE Technology}

As a common tool, the computer has been widely used in all walks of life, especially in the industrial design department. In this trend, the computer application should strengthen the graduation design, not only to encourage the students to use the computer to draw drawings and specifications, but also should strengthen learning, research and application of $\mathrm{CAD} / \mathrm{CAE}$ technology, improve the application ability of $\mathrm{CAD} / \mathrm{CAE}$ students.

The graduation design is a scientific practice, the ultimate aim is to carry forward the tradition of innovation, each student has the ability to innovate, but whether there is innovation and innovation is bound to the existence of the objective conditions and whether he can make their own creative breakthrough ideas. Through a series of activities to guide teachers to guide students to study, in line with the materialism view, from reality, develop thinking, in specific work, lack of courage to criticism of their predecessors, to absorb the strengths of others, to further explore ways to improve. In this way, on the one hand, the future of the graduates to point out the direction, on the other hand, the cultivation of innovative awareness, the development of students' life is far-reaching.

\section{Inspire students to take initiative in thinking}

Design from the formulation of the program, the principle, to the structural design, should be to the end of the final scientific and creative thinking training and requirements. Thinking from doubt, teachers should combine the actual content of the design to constantly raise questions to stimulate students' thinking, so as to improve students' ability to analyze and solve problems. Be to speed up their development of scientific research and engineering design, and to shorten the period of self-exploration in the society in scientific research and engineering design.

\section{E. Develop students' ability to work}

Students just contact topics, on the subject of the content is not understand, I do not know how to start, the instructor in the task book at the same time, should teach the students to collect and retrieve data to train the students to use eyes to read data. After students have a certain understanding of the subject, teachers take the important way to guide the students to use the knowledge to solve the problem for you to check the information, to explore, to practice.

\section{STRICT INSPECTION SYSTEM, STANDARDIZED PERFormance EVALUATION}

The effective way to improve the quality of graduation design is the strict examination system and the graduation reply and the standard grade evaluation method.

\section{A. Strict inspection system}

In the graduation design, according to the teaching requirements, strict requirements for students, formulate strict teaching requirements, adhere to strict classroom discipline, strict control of students absent, cultivate student rigorous academic atmosphere. The teacher should strengthen the guidance on students' assessment and supervision and inspection, and the good opening design, regularly check the graduation design work, in view of the problems timely solve the relevant information and feedback, the Council held up, conscientiously sum up each process problem and experience, at the same time the initial inspection and mid-term assessment phase together, let the students aware of their shortcomings, otherwise, wait until graduation to find problems, redo too late, too late

\section{B. Graduation design achievement evaluation be scientific [3]}

The scientific evaluation index system and evaluation criteria is established and improved. The achievement evaluation of graduation design is a comprehensive examination and evaluation of the quality of graduation design teaching. The quality assessment seriously, not only can objectively evaluate students to master and use knowledge to solve the question ability, but also can reflect students' 
comprehensive quality, therefore, in order to objectively evaluate the quality of graduation design of each student, must adhere to objective and impartial, strict and unified principle, the establishment of a comprehensive evaluation index the system more scientific and standard for evaluation, the index system should cover the whole process of the graduation design, including the design of attitude, students in the process of design performance, design quality and complete all the design documents, the quality of the graduation reply effect, at the same time the error and correct attitude etc. the teacher pointed out in the review process and reply.

\section{Strict graduation reply}

The graduation thesis is the last important part in the graduation design process. Although the time is tight, but because it is an important link, it is absolutely not omitted or simplified. We can use the combination of centralized reply and group defense, but the teacher should guarantee a certain amount, and still require students to tell the teacher on the podium and the question and answer [4]. This form allows students to feel that graduation is a serious matter, but also the ability to exercise the students. When the graduation reply, because of the time reason is often only pay attention to the beginning of a small part of the students, and the defense of the other students is too simple. This caused a bad impression on the students that the graduation reply is to walk through the field. This will often cause a chain reaction: the way the graduation reply will affect the next generation of graduates to do graduate design attitude, especially for some students, do not think to do graduate design anyway, never mind, easily through the defense.

Graduate students in the graduate design results in the proportion of the larger, it is the quality of graduation project design objective, impartial assessment and evaluation [5], which requires strict, standardized, and scientific. The Defense Committee assessment approach, not only increased the pressure on students, the usual sense of design task, not as a mere formality, but also enhance the evaluation of teachers' responsibility graduation design performance should be taken into account, the specific contents include the workload, the design level, the level, the ability to work independently, in reply, for the students of different levels, teachers can make different demands on the same design topics, such as the basic requirements and higher requirements, the highest requirements, each corresponding to different performance requirements, this approach is conducive to arouse students' enthusiasm and spirit[6].

Graduation design is an important practical link in the teaching plan, which is related to whether the graduates of the school can be recognized and accepted by the society. As long as teachers and students work together, pragmatic work, and effectively improve the quality of graduation design, improve the skills of students, in order to train more people with good quality of engineers.

\section{ACKNOWLEDGEMENTS}

This paper is supported by the Education and Research Project of Taiyuan University of Science and technology
(No.11), Shanxi graduate education reform program (No.2015JG11) and the postgraduate education reform project of Taiyuan university of science and technology (No.20133015).

\section{REFERENCE}

[1] Chen Yuanfang. Graduation design guide for hydrology and water resources engineering [M]. Beijing: China Water Conservancy and Hydropower Press, 2000

[2] Liao Zhiling et al. Problems and solutions in the design of undergraduate course graduation [J]. Journal of Jiangsu University 2004.4

[3] Influence factors and Countermeasures of the quality of graduation design teaching $[\mathrm{J}]$. Heilongjiang higher education research.2001.5

[4] Department of higher education of the Ministry of education. Higher education reform [M]. Beijing: Higher Education Press, 1999.

[5] Chen Huajiang, Chen Jianeng. Thinking and Discussion on the teaching process of graduation design [M]. Journal of Chongqing College of industry and technology.2004.6

[6] Cao Qingshan. Higher mathematics course construction and teaching reform research and practice, reformation of examination evaluation ways, 2008 (23). 